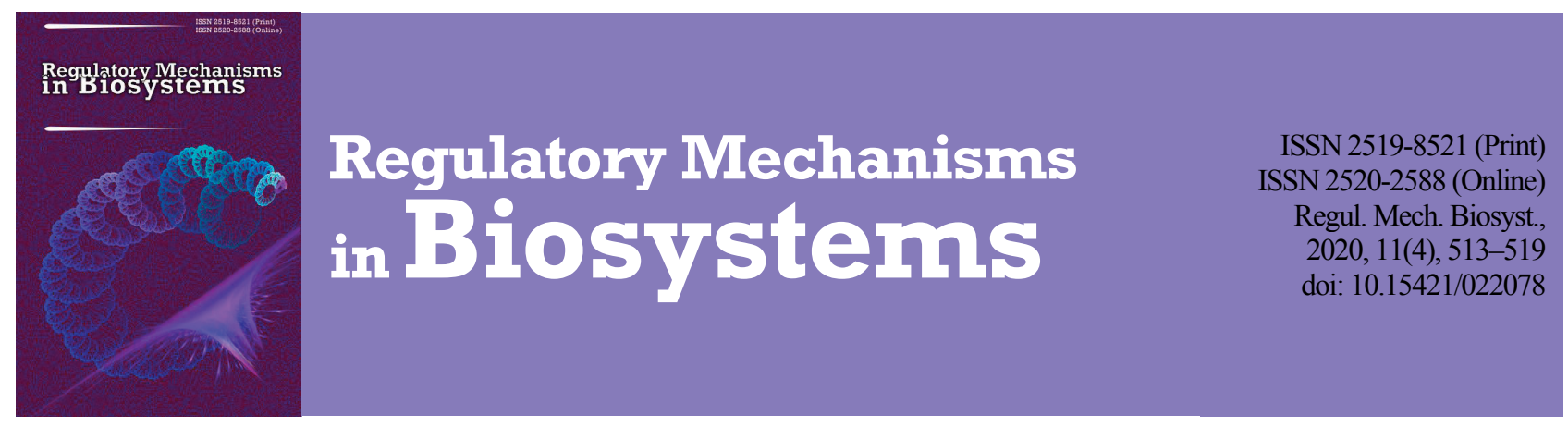

\title{
Morpho-anatomical structure and development of fruit in Asyneuma canescens (Campanulaceae)
}

\author{
R. R. Andreychuk*, V. P. Kolomiychuk**, A. V. Odintsova* \\ *Ivan Franko National University of Lviv, Lviv, Ukraine \\ **Taras Shevchenko National University of Kyiv, Kyiv, Ukraine
}

Article info

Received 10.10.2020

Received in revised form

05.11 .2020

Accepted 07.11.2020

Ivan Franko National

University of Lviv,

Hrushevskyi st., 4,

Lviv, 79005, Ukraine.

Tel.: +38-067-705-24-06

E-mail: roksolanaandre

chuk01@gmail.com

Taras Shevchenko

National University

of Kyiv, Volodymyrska st.,

60, Kyiv, 01033, Ukraine

Tel.: +38-067-612-31-79.

E-mail:

vkolomiychuk@ukr.net

\author{
Andreychuk, R. R., Kolomiychuk, V. P., \& Odintsova, A. V. (2020). Morpho-anatomical structure and development of fruit in Asy- \\ neuma canescens (Campanulaceae). Regulatory Mechanisms in Biosystems, 11(4), 513-519. doi:10.15421/022078
}

The most usual fruit type in the family Campanulaceae is an inferior multi-seeded capsule. In Campanula and related genera, A. Kolakovsky determined a new type of capsule, characterized by a specialized organ, axicorn. Some types of axicorn capsules were determined depending on the way of dehiscence. In Campanula, capsule dehiscence is called axicorn-fissuricidal mode, while in Asyneuma - axicorn-valvate mode with scaliformis valves. The precise differences between slit and valve so far have not been identified. In this connection, we performed the study of the inner fruit structure and dehiscence in Asyneuma canescens intending to compare the results with those for Campanula species. Anatomical fruit structure was studied under a light microscope on temporary preparations of transversal and longitudinal sections. For the first time, the obtained data provide precise characteristics of the inner fruit morphology, the anatomy of the fruit wall, and dehiscence mode in A. canescens. The survey revealed predominance in the ovary of a synascidiate zone with axile placentation. In the anatomical structure of the fruit wall, there we found a parenchymatous mesocarpium, non-lignified exo- and endocarpium, and lignified elements of fruit - axicorns, located in the small upper part of the septa. Fruit dehiscence in A. canescens occurs in two steps. First, during early flower development, narrow-oval dips are formed on the septum radii; during the fruiting period, a hippocrepiform slit at the lower margin of each dip develops. At this time axicorns detach from the central column of the ovary following a curved direction, meaning the formation of the septifragal slit. During the second stage, the longitudinal slits are formed from the lowest point of the hippocrepiform slit to the fruit base. These slits facilitate seed release from the capsule. Fruit in $A$. canescens we define as an inferior trilocular syncarpous capsule with two-stage, hippocrepiform and laminar dehiscence. Our study confirms resemblance of anatomical structure and dehiscence mode of fruit in A. canescens and species of the section Rapunculus of the genus Campanula with erect capsules. We consider it inexpedient to accept the new fruit type for $A$. canescens, because differences compared with species of Campanula are derivative and concern the small size of the axicorn slit and the appearance of additional slits only.

Keywords: bellflower family; inferior ovary; capsular fruit; axicorn; fruit dehiscence; seed; fruit wall.

\section{Introduction}

Since the beginning of study of the family Campanulaceae Juss., the great morphological diversity of capsular fruits was revealed in it (Kolakovsky 1995; Lammers, 2007). As our previous review of the question showed (Andreychuk \& Odintsova, 2020), this diversity has still not been appropriately evaluated from anatomical and evolutionary-morphological perspectives. Consequently, it cannot be used to the full extent in the family systematics. The study of fruit morphogenesis and histogenesis of the fruit wall is a valuable method of evolutionary-carpological researches (Bobrov \& Romanov, 2019). Detailed morphological analysis of the fruits and the types of fruit dehiscence in Campanulaceae was performed by Kolakovsky (1995), who established a new fruit type for many genera of the bellflower family - axicorn capsule, characterized by presence of specialized organ - axicorn. According to Kolakovsky (1995), genera Asyneuma Griseb. \& Schenk., Neocodon Kolak. et Serd. and Favratia Feer are characterized by axicorn-valvate fruit type with scaliform valves (porus membranaceus scaliformis). It operates in the following procedure: in the upper part of the capsule, depressions of thin tissue of the fruit wall occur in the form of semi-spherical "sacks". To their bases, the beaks of tiny axicorns are connected. They open small pieces of the fruit wall in the previously outlined positions, usually, near the sepal bases. Kolakovsky (1995) named such a type of opening a valve or a valvate pore (porus membranaceus). In the monograph of Kolakovsky (1995), there are schematic drawings of longitudinal and transversal sections of the fruit in Asyneuma canescens (Waldst. \& Kit.) Griseb. \& Schenk, a species with axicorn-valvate fruit type, depicting the position of axicorns and placentas in the upper part of the fruit, with axicorns as parts of fruit septa. It is noted that the capsule of $A$. canescens is notably narrowed near its top, opens through tongue-shaped axicorn attached to the very top of the central column. Capsule walls are thin, transparent. Skeletal veins of the fruit are narrow, with well-developed anastomoses. The central column is prominent, placentas are small, tongue-shaped (Kolakovsky, 1995). This short description of the fruit in A. canescens partly correspond to the description of the fruit in Campanula latifolia L., studied by us (Andreychuk \& Odintsova, 2019).

Peculiarities of the fruit in the species of the genus Campanula are the varying positions of axicorns: in the upper or the lower part of the capsule (Kolakovsky, 1995). However, fruit in Campanula species, according to Kolakovsky, belongs to axicorn-fissuricidal carpological type. This type is characterized by axicorn, making a hipocrepiform slit with its beak on the fruit wall, between skeletal veins, by the way of spreading the tissues. Axicorn splits in the fruits (fissura axicornuta) were also reported for genera Phyteuma L. and Adenophora Fisch. (Kolakovsky, 1995). In genera Legousia Durande and Cylindrocarpa Rgl., Kolakovsky (1995) described the axicorn opening, named as flat valve (porus membranaceus platyphyllus) - an elongated, usually wedge-like opening in the upper part of the capsule, often with torn margins; it is formed by the whole surface 
of flat axicorn bending outward, fusing with the fruit wall. The genera Asyneuma, Phyteuma, Legousia, Adenophora, and Campanula have representatives in the flora of Ukraine (Mosyakin \& Fedoronchuk, 1999) and are considered to be closely related. Molecular phylogenetical data confirm that representatives of Asyneuma belong to Rapunculus-clade of Campanula genus (Eddie et al., 2003; Roquet et al., 2008, 2009; Haberle et al., 2009; Zhuo et al., 2011), together with morphologically diverse genera Adenophora, Heterocodon Nutt., Homocodon D. Y. Hong, Githopsis Nutt., Legousia, Phyteuma, Petromarula Vent. ex R. Hedw., Physoplexis (Endl.) Schur, Trachelium L., Triodanis Raf. and Campanula p. p., for example, $C$. persicifolia $\mathrm{L}$. According to the other data (Borsch et al., 2009), representatives of the genus Asyneuma (A. canescens, A. campanuloides) belong to the Phyteuma-clade together with genera Phyteuma, Physoplexis, Petromarula, Legousia, and some Campanula species. Chemotaxonomical investigation of 25 Korean species of Campanulaceae from 8 genera showed that Asyneuma and Peracarpa Hook. f. et Thoms. are the most similar according to the composition of the marker molecules used in pharmacopeia (Kim et al., 2017). Genus Asyneuma is considered to be a polyphyletic group of species (Stefanovich \& Lakušić, 2009; Mansion et al., 2012; Yoo et al., 2018).

In contrast to Campanula and Adenophora with bell-formed corolla, Asyneuma, Phyteuma, and Physoplexis have a deeply dissected corolla with a short tubular part (Zhuo et al., 2011). In Asyneuma japonicum (Miq.) Briq., a white-flower form was found (Fedina et al., 2016).

Therefore, despite the availability of the data on external fruit structure, presence of axicorns in the species of Campanulaceae and phylogenetical relations of the genus Campanula with the other close related genera, the precise differences between modes of fruit dehiscence through scaliform valve, flat valve, and axicorn slit still remain unclear. There is no data on the anatomical structure of the fruit wall and micromorphology of the gynoecium. Therefore, we decided to conduct a study on the fruit structure and fruit dehiscence in one representative of the genus Asyneuma for the comparison with the data, obtained for the genus Campanula.

The genus Asyneuma belongs to the subfamily Campanuloideae of family Campanulaceae. The genus comprises annual, biennial, perennial herbs, with thin rhizome or spindle-like root. Leaves are short-petiolate, stem-born, or rosulate. Flowers are small, or average-sized, sessile, grouped in simple or branched spikes or dense cylindric heads. Corolla is purple, blue, or white, divided almost to the base. Filaments are broadened in the base. The ovary is (2-)3(-4)-locular, stigma lobes are linear. Fruit is capsular, dehiscent laterally through 2-3 medial or subapical pores. The genus comprises 33 species inhabiting Asia, Eastern Europe, Northern Africa (Lammers, 2007).

Species of Asyneuma were recently studied mostly in palynomorphological aspect. Alçitepe (2008) provided detailed information on morphological, anatomical, and palynological characteristics of Asyneuma michauxioides (Boiss.) Damboldt, endemic to Turkey. It was noted that pollen grains are triporate, sometimes tetraporate, with equatorially located pores. In Asyneuma limonifolium (L.) Janchen, the pollen grains are isopolar, radially-symmetric, with 4 or 5 pores (Kallajxhiu et al., 2014). Based on the palynological data, genera Asyneuma, Legousia, Michauxia L'Hér, Symphyandra A. DC., Theodorovia Kolak. and Zeugandra P. H. Davis are not differentiated from the Campanula (Khansari et al., 2012). Pollen grains in A. canescens have average size, spherical, tetraporate, with echinate and striate-microreticulate surface. In other Asyneuma species, pollen grains are usually 4-5-porate (Halbritter, 2016. In: PalDat - A palynological database. An online publication on recent pollen. Available at: www.paldat.org/pub/Asyneuma_canescens/300857).

Asyneuma canescens (Graue Traubenrapunzel, in German) is the only species of the genus in the flora of Ukraine (Mosyakin \& Fedoronchuk, 1999), grows in the southern regions of forest-steppe, in the steppe, in the Crimea forest-steppe, and on rocky places in the northern part of the Southern Crimea (Visyulina, 1961). The total range of $A$. canescens covers Southern-East Europe - Albania, Bulgaria, the Czech Republic, Slovakia, Greece, Hungary, Romania, Ukraine, Moldova, Russia, Croatia, Bosnia and Herzegovina, Montenegro, Serbia (including the Republic of Kosovo and Vojvodina) (POWO, 2019. Plants of the World Online. Facilitated by the Royal Botanic Gardens, Kew, www.plantsoftheworldonline.org).
The plant is densely covered with leaves, short-pubescent or rarely almost glabrous stem, $30-126 \mathrm{~cm}$ heigh. Rosulate and lower stem leaves are petiolate, middle and upper leaves are sessile; rosulate leaves are ovoid, up to $15 \mathrm{~cm}$ long, lower stem leaves - elongated, serrate at margins, upper leaves are narrow-lanceolate, with almost entire margins. Flowers are about $1 \mathrm{~cm}$ long, on short peduncles, form a long, spike-like inflorescence in axils of green upper leaves; rarely inflorescence is branched, with spike-like branches. The calyx is penta-lobed, with glabrous linear-lanceolate lobes. The corolla is deeply divided into 5 segments, $8-10 \mathrm{~mm}$ long, with linear segments, light purple, externally pubescent. The capsule is trilocular, elongated, openings are lateral (Visyulina, 1961). A special study on fruit anatomy of this species has not been carried out previously.

\section{Materials and methods}

Collection of material. For the search of the material of A. canescens in the territory of Ukraine, there were organized two expedition trips to the Savur Mohyla tract (June 10 and July 7, 2019), located on the eastern outskirts of Hryhorivka village in the Zaporizhia district of Zaporizhia oblast (site coordinates: 47070’60” N, 35'38'60”'E).

Flowers and fruits of $A$. canescens at different stages of the development were photographed and collected by V. P. Kolomiychuk on the steep steppe slopes of the western exposition of the Savur Mohyla where the studied species grows singly on gravelly soils. Populations of this species were observed within the association of Festucetum valesiaceae varioherbosum characterized by low projective cover (40-50\%) and relatively low species richness (15-20 species of vascular plants per $100 \mathrm{~m}^{2}$ ). In the association, the species of Eurasian-steppe type of the range dominates $(42.6 \%)$ - there were species of Pontic, Eurasian steppe, Black Sea ranges. Also, there were collected three herbarium specimens of $A$. canescens, two of which were transferred to the National Herbarium of Ukraine $(\mathrm{KW})$ and one was stored in the O. V. Fomin Botanical Garden herbarium (KWHU).

Morphological and microscopic methods. The material was fixed in $70 \%$ ethanol. To process the material in the laboratory, we analyzed 510 flowers and fruits at different stages of development from the floral bud stage to the stage of the complete destruction of the fruit wall. The morphological structure of the flower and the fruit was studied on total preparations of transverse and longitudinal sections of the fruit made with a blade. We used stereo- microscope MBS-10, measurements were made using a measuring ocular. The anatomical structure of the fruit was studied using transverse and longitudinal sections on temporary preparations prepared in the water on a glass slide. On the temporary preparations, we made a reaction to tissue lignifying with an alcoholic solution of phloroglucinol and 10\% hydrochloric acid (Barykina et al., 2004). Anatomical sections were examined at $\mathrm{x} 4$ and $\times 10$ magnifications of the ocular of XS2610 light microscope. The AmScope MD digital ocular and AmScope 3.7 software were used to take images of the sections.

Morphological descriptions of the fruits were carried out according to the method of composing carpological descriptions according to Kaden \& Smirnova (1974) using generally adopted terminology (Artjuschenko \& Theodorov, 1986). The structure of the fruit wall was studied according to Roth (1977) who designated histological zones of exo-, meso- and endocarpium in the pericarp, which corresponded to the outer epidermis, mesophyll, and inner epidermis of the fruit wall, regardless of the origin of the tissues from the carpels or extracarpellary structures.

\section{Results}

Morphological structure of flower and fruit. Flowers of $A$. canescens are $10-12 \mathrm{~mm}$ in length and $1.5-2.0 \mathrm{~mm}$ in diameter (Fig. 1, 2). Sepals are $3 \mathrm{~mm}$ in length, inferior ovary also $3 \mathrm{~mm}$ in length. The sepals are directed upwards. The number of sepals varied from 5 to 7 and they were densely pressed to the corolla, lanceolate. The plant has five petals fused only at the base, linear, $7 \mathrm{~mm}$ in length; and five stamens with long anthers. The style is long, slightly exserted from the corolla, the stigma is three-lobed. The fruit of $A$. canescens is an inferior dry capsule. The capsule is $5-7 \mathrm{~mm}$ in length and $3.0-3.5 \mathrm{~mm}$ in diameter, elongatedcylindrical in shape, ribbed, erect. 


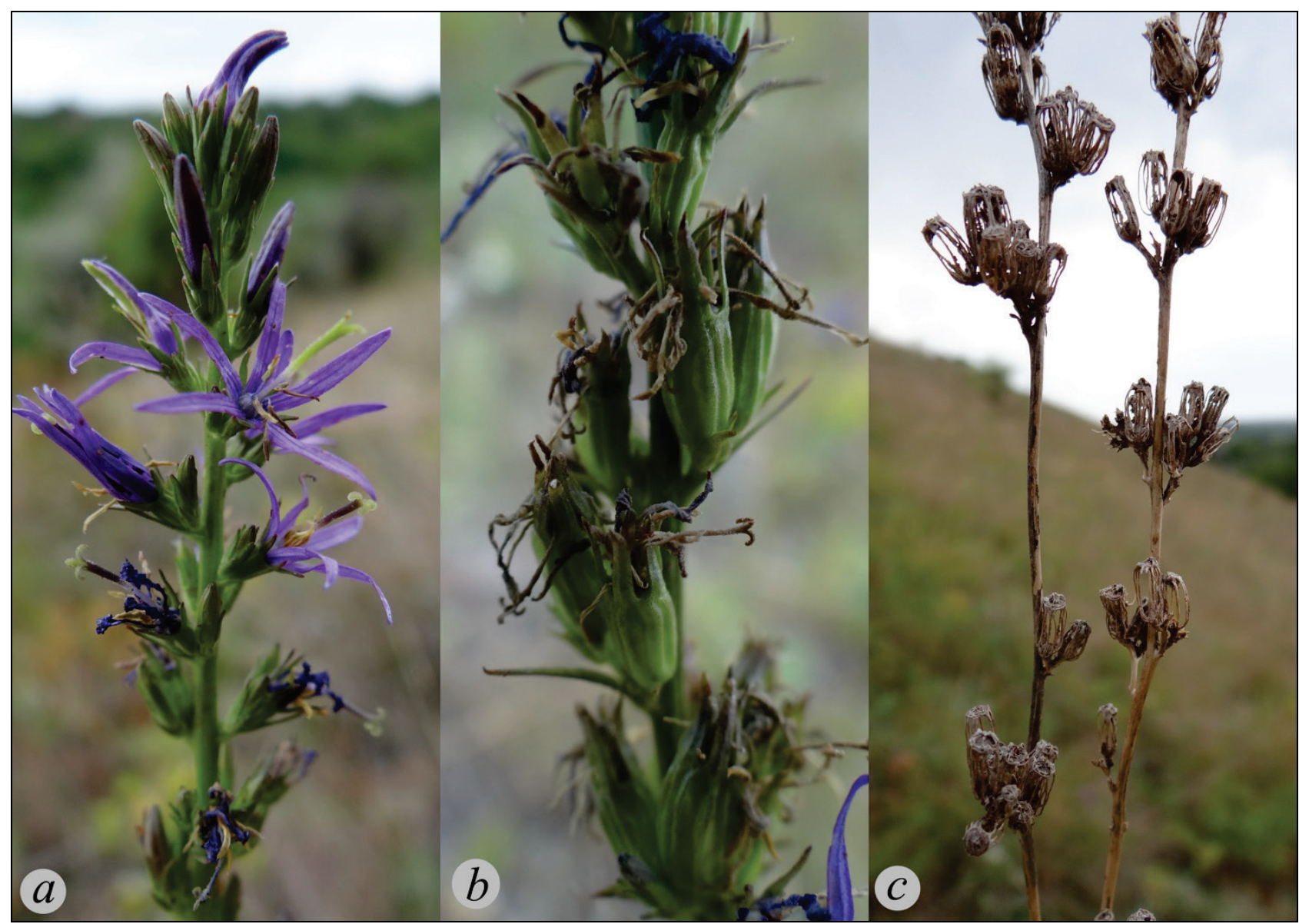

Fig. 1. General view of the inflorescence of $A$. canescens at different stages of the development: $a$ - flowering, $b$ - fruiting, $c$-after dissemination

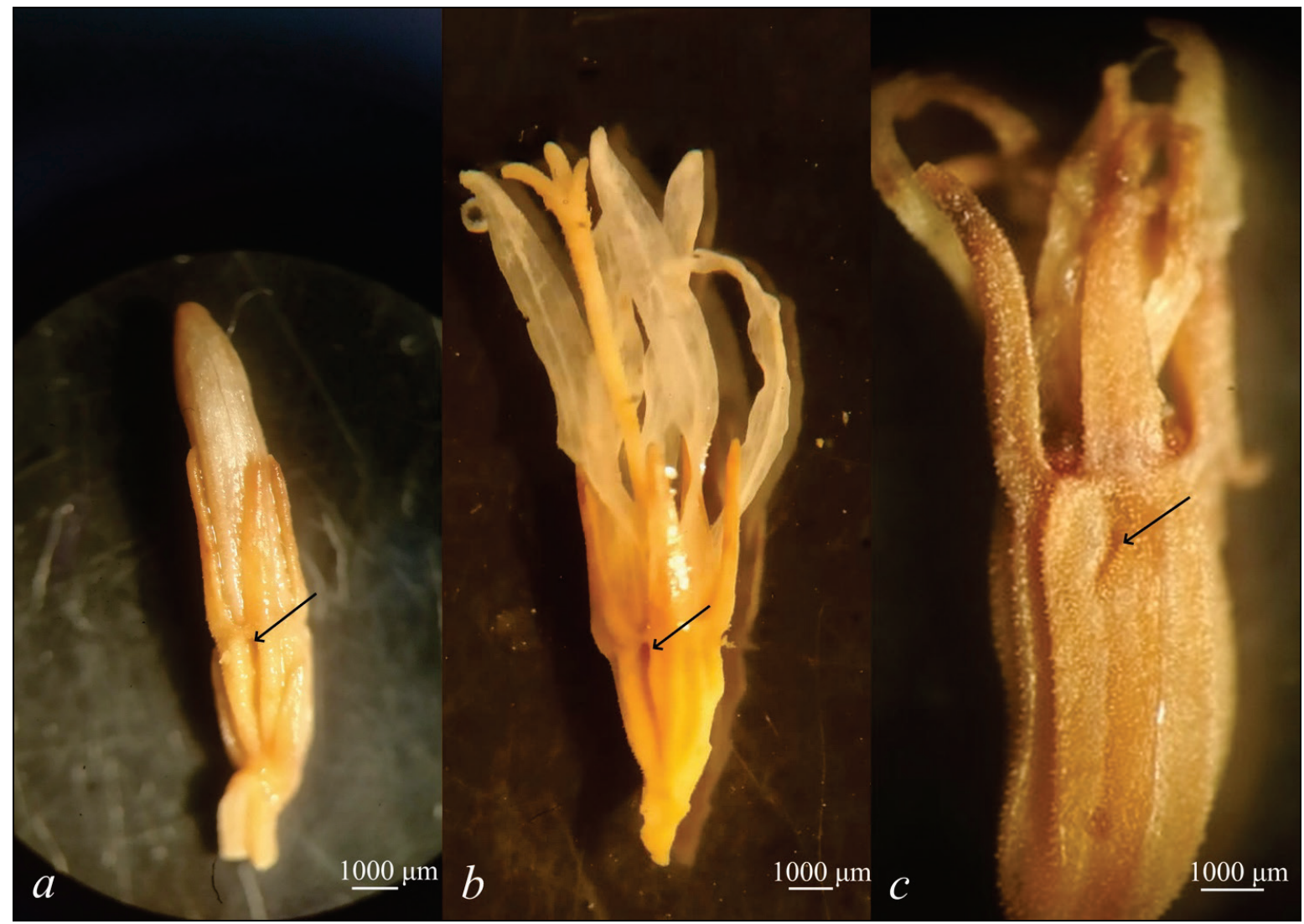

Fig. 2. Fixed flowers of $A$. canescens at different stages of the development: $a$-floral bud, $b$-anthesis, $c$ - post-anthetic phase; the arrow shows a dip in the ovary wall at the place of the future opening 
The surface of the fruit and sepals is covered with hairs (Fig. 2, 3b, 6). The peduncle is very short, about $1-2 \mathrm{~mm}$ in length and $1-2 \mathrm{~mm}$ in diameter. The corolla, stamens, and the style remain for some time in the fruit (Fig. 1b). Later, when the fruit is drying, these floral parts curl and fall off. Ripe dried fruit has no sepals (Fig. 3a). During the drying of the fruit after dissemination, the parenchyma of the fruit wall decays, and only vascular bundles and lignified elements remain visible (Fig. 1c).

In the upper part of the fruit, in the interfascicular areas, at the places where the slit of the fruit will be formed, there are three (sometimes two) dips with elongated shape (Fig. 2). These dips are evident at the floral bud stage (Fig. 2a). After some time, the dips become deeper and more noticeable at the upper part (Fig. 3a). We studied the internal structure of the mature capsule of $A$. canescens (at the stage of opening formation) on temporary preparations (Fig. 3, 4). On the longitudinal section, we noticed placentas above the middle of the ovary height. The lobes of the placentas bend upward and downward, and the seeds are attached to them (Fig. 3b).

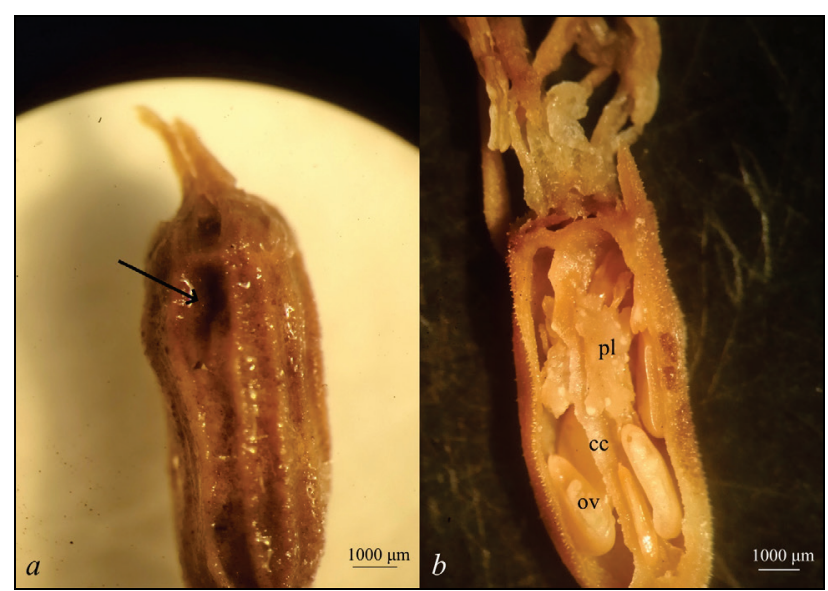

Fig. 3. Morphological structure of the fruit of $A$. canescens: $a$-general view of the fruit, dip at the place of the opening is shown with the arrow, $b$ - internal structure of the fruit: $p l$-placenta, $c c$ - central column, ov-ovule

In the central part of the fruit, there is a central column which has a triangular shape at the base of the fruit on the cross-sections. The central column integrally extends from the base to the top of the fruit (Fig. 3b). The roof of the ovary is flat, not thickened (Fig. 3b). On the cross-sections, we noticed that the capsule is round and thin-walled. It has three locules that are separated by thin septa. In the upper part of the fruit, the septa of the ovary are short and the capsule has deep grooves at the lines of carpels' fusion (Fig. 4, 5).

The capsule contains $5-10$ seeds. The seeds are $1.0-1.5 \mathrm{~mm}$ in length and $1.0 \mathrm{~mm}$ in width, oval, slightly elongated, light brown, slightly flattened, compressed on one side, forming a narrow wing (Fig. 4).

Anatomical structure of the fruit. The exocarpium is unlignified and consists of one layer of cells. The cross-sections show that the exocarpium is densely covered with small spiny hairs with unlignified walls (Fig. 6). The hairs are unicellular. The mesocarpium consists of 7-15 layers of cells, thickened in the ribs, unlignified. At the early stages of the fruit development, the mesocarpium is differentiated into external photosynthetic parenchyma and internal ground parenchyma (Fig. 6). The endocarpium has one layer of cells, unlignified (Fig. 6).

The vascular system of $A$. canescens fruit is represented by 9-12 ascending vascular bundles in the ovary wall, which pass along the ribs, and a ring of vascular tissues in the central column (Fig. 4, 5a), which further higher splits into three or more vascular bundles opposite the septa. Sometimes there are three larger and several smaller bundles (Fig. 5b). Usually, in the middle of the ovary height, in the fruit wall there are 10 vascular bundles in the ribs (Fig. 4a, 4e, 6) and a few small branches. On the septum radii, no vascular bundles pass, so three or four bundles go through the portion of each of the three carpels (Fig. 4). At the level of the ovary roof, the ascending bundles form horizontal branches - the girdling vascular bundle (Fig. 4f). The traces of sepals, petals, and stamens are formed from it. Six vascular bundles enter the style - three dorsal bundles of car- pels and three vascular bundles from the central column of the ovary (Fig. 4e, 4f).

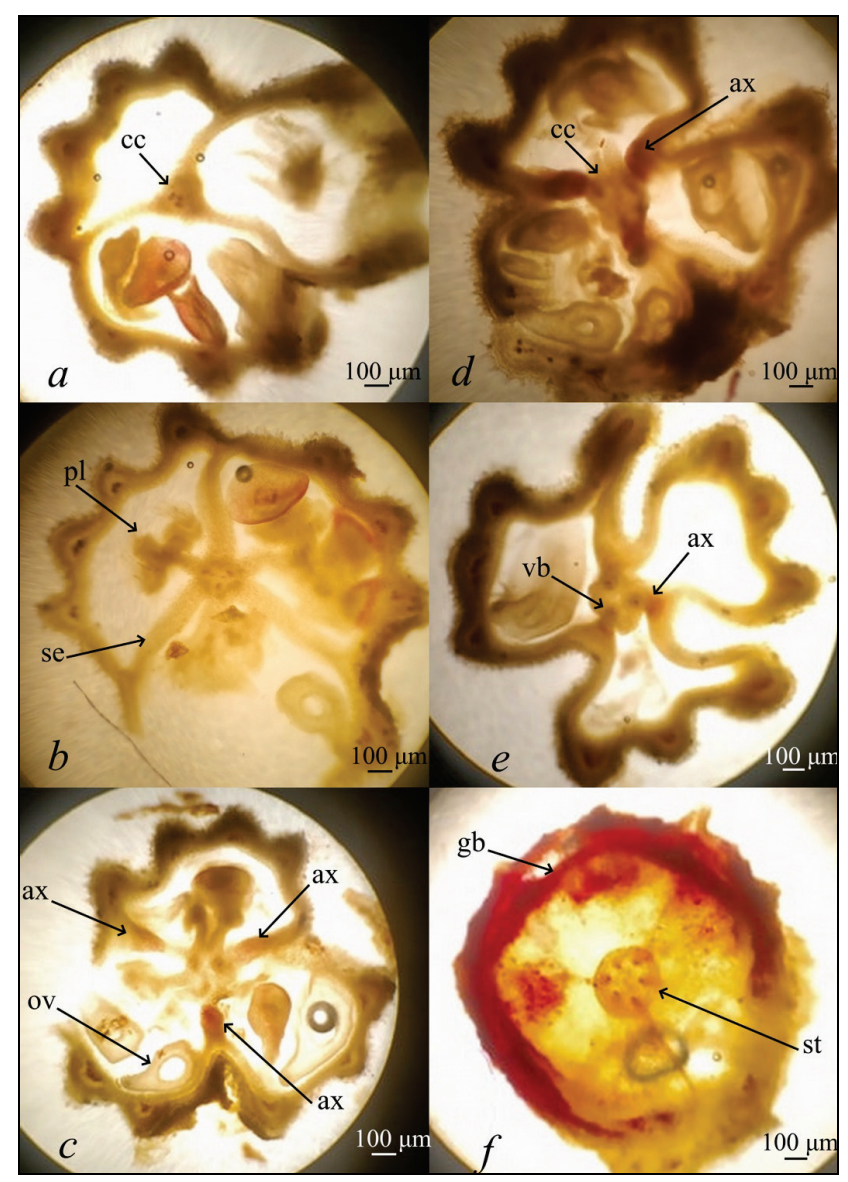

Fig. 4. An ascending series of transversal sections of the fruit of $A$. canescens (fixed material, reaction with phloroglucinol): $a x$-axicorn, $c c$-central column, $g b$ - girdling vascular bundle, $o v$ - ovule, $p l$ - placenta, $s e$ - septa, $s t$ - style, $v b$ - vascular bundle

In the upper part of the fruit above the placenta in the proximal parts of the septa, there are three visible weakly developed axicorns which are attached to the central column (Fig. 4d). In the cross-sections, the axicorns have a rounded shape, and their beaks orient the axicorns downward toward the fruit wall under an angle. In the longitudinal section, the axicorn has a tonguelike curved shape (Fig. 7, 8b). The reaction for the lignified tissues showed that the axicorns are an area with lignified parenchyma in the septa of the fruit (Fig. 5). The cells of the epidermis, which cover the axicorns, are small, unlignified.

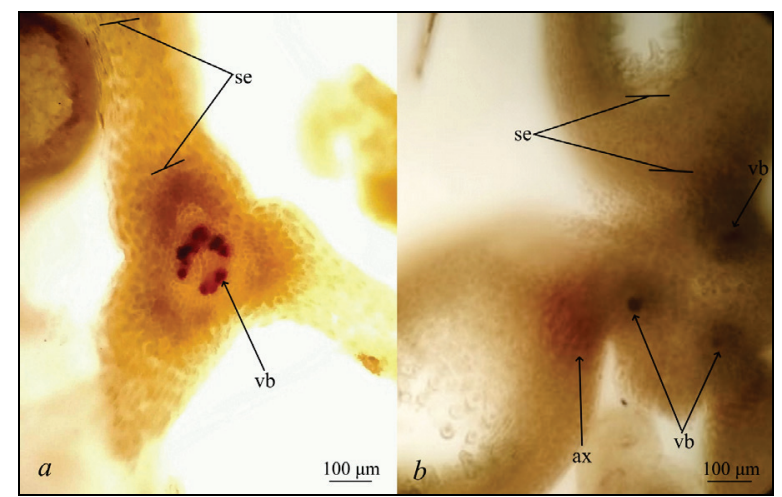

Fig. 5. Central column with septa of the fruit of $A$. canescens (fixed material, reaction with phloroglucinol): $a$ - section at the lower part of the fruit, $b$-section at the upper part of the fruit at the level of axicorns; $a x$-axicom, se-septum of the fruit (septum is significantly longer at the first section in comparison with the second), $v b$-vascular bundle 


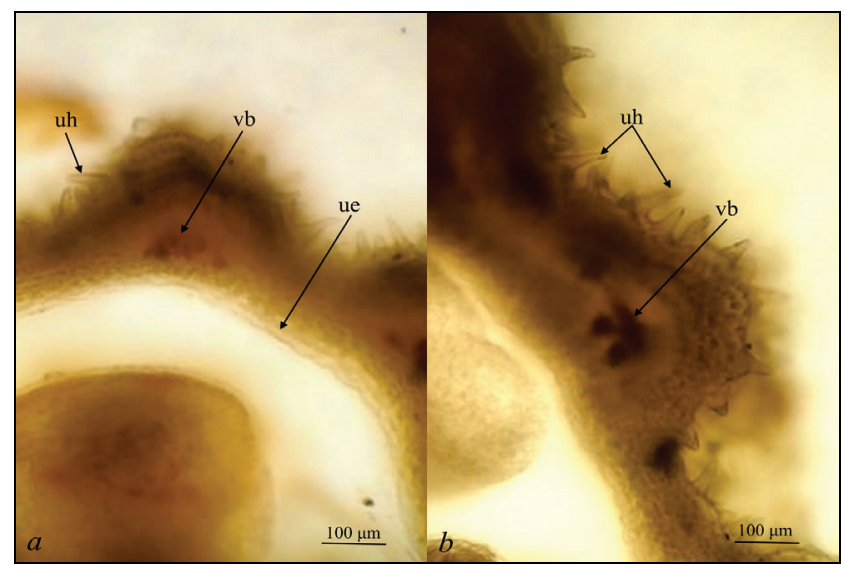

Fig. 6. The parts of the fruit wall of $A$. canescens (fixed material, reaction with phloroglucinol): vascular bundles $(v b)$ in the ribs of the fruit, unlignified endocarpium $(u e)$ and unicellular hairs $(u h)$
Dehiscence of the fruit. Dehiscence of the fruit of $A$. canescens is carried out in two stages. First, when the fruit is maturing, in the upper part of the fruit, the bundles become more distant from each other, thus forming an oval-shaped dip (Fig. 3a). An axicorn participates in fruit dehiscence with its beak, which is attached to the fruit wall, breaks the area of the fruit wall in the lower edge of the dip. In this way, the axicorn forms a hippocrepiform (horse-shoe-shaped) slit covered with a valve (Fig. 7a). When the valve bends outwards, the axicorn's beak is becomes visible in the lower part, making the lower edge of the valve look spiky (Fig. 7c, 8a). Because the dip in the fruit wall is narrow it seems that the opening is a crack or pore, or a wedge-shaped slit but the shape of the opening is narrow-oval and the slit is hippocrepiform, not triangular (Fig. 7a, 7c). The valve (slit) in the ripe dried fruit is $1.5-1.7 \mathrm{~mm}$ in length and 1.0 $1.5 \mathrm{~mm}$ in width. Gradually, the dip becomes pressed more and the lower edge bends outward, creating an opening for the release of seeds during shaking. The valve is very narrow, does not exceed the size of the seed, making it difficult to disseminate. When the opening is developing, the fruit septum detaches from the central column and breaks along the lower edge of the axicorns in a curving direction (Fig. 8b).

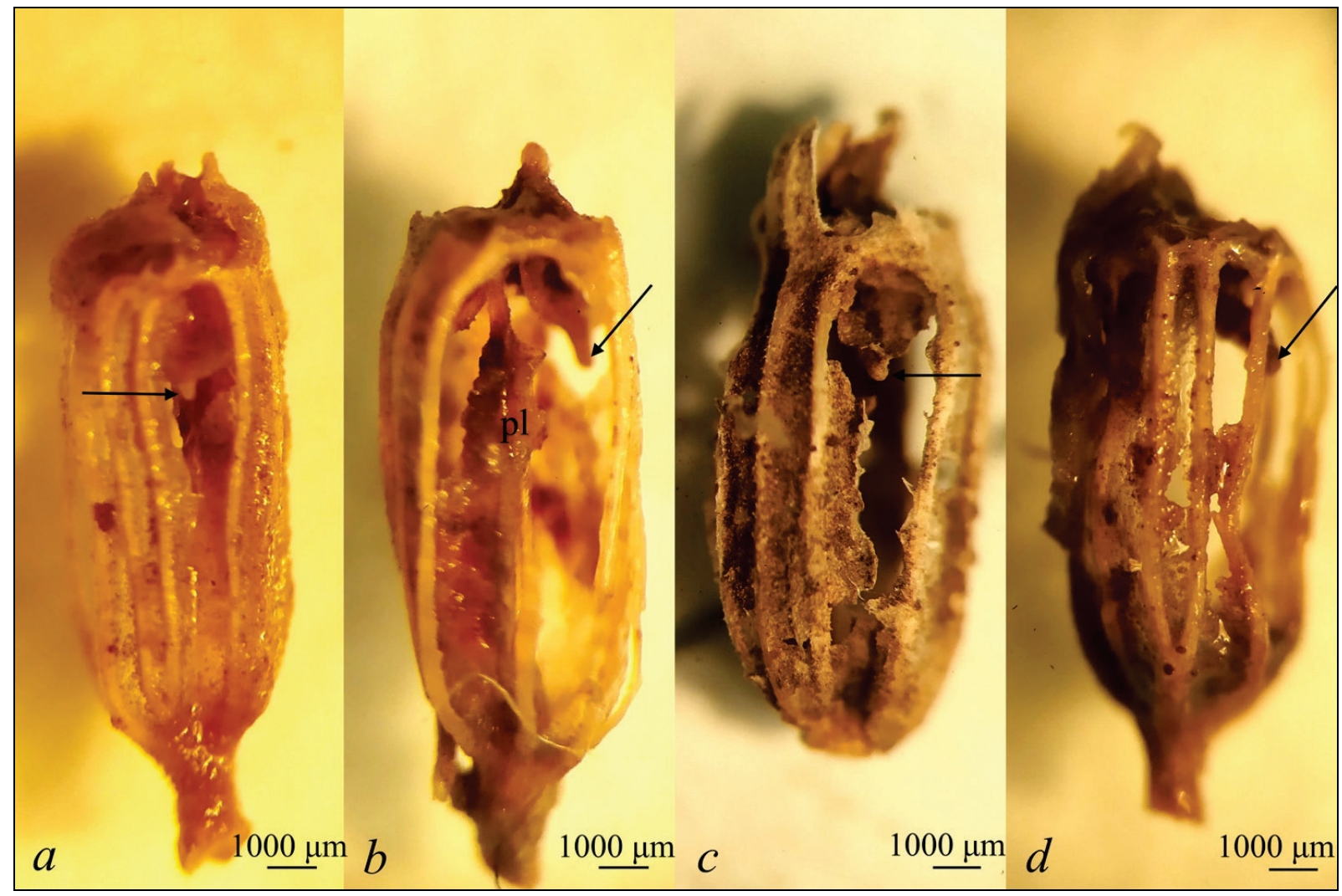

Fig. 7. Dehiscence stages of the fruit $A$. canescens: $a$-fruit dehiscence through hippocrepiform slit (stage 1), $b$-longitudinal section of the opened fruit, axicorn's beak and placentas are noticeable $(p l), c$ - fruit dehiscence through the longitudinal slit (stage 2$), d$-destruction of the pericarp after dissemination, only vascular bundles and axicorns retained; the axicorn's beak is marked with an arrow

Stage 2 of the fruit dehiscence continues with the formation of a longitudinal slit from the lower point of the hippocrepiform slit almost to the base of the fruit (Fig. 7c, 8a). This slit facilitates the seeds' release. At the later stages of fruit morphogenesis, the fruit septa are destroyed and the parenchyma of the fruit wall gradually decays to complete destruction (Fig. 7d). In the completely dried fruit, after dissemination, there remain the central column, ascendant bundles, and axicorns holding the valves remain.

\section{Discussion}

The obtained data for the first time allow us to analyze precisely the inner structure of the fruit, anatomy of the fruit wall, and dehiscence in A. canescens. We revealed completely closed locules of the ovary up to the placental level and above. Septa of the ovary are completely fused with central column, which is characteristics of synascydiate zone of the gynoecium. Placenta, located in this zone, is axile. According to the data
Bojňanský \& Fargašová (2007), which correlate with our data, A. canescens has elliptic seeds with truncate top and narrowed base, $1.5-1.7$ x 0.7 $0.9 \mathrm{~mm}$. The seed surface is glabrous, glossy, brown, with black basis. For A. canescens, Kolakovsky (1995) reported elongated flattened seeds, up to $2.0 \mathrm{~mm}$ in length, narrow-winged from one side. Another studied species, A. michauxioides, has elliptic, brown, compressed from one side, glabrous and glossy seeds, $0.8-1.0 \mathrm{~mm}$ in length, $0.4-0.5 \mathrm{~mm}$ in width (Alçitepe, 2008). A. comosiforme Hayek \& Janch. has reddish to dark brown seeds, $0.8-0.9 \mathrm{~mm}$ in length, $0.5-0.6 \mathrm{~mm}$ in width, flattened, or ellipsoidal (Lakušić et al., 2019).

The seeds in different species of Asyneuma are morphologically very similar to seeds of genera Phyteuma and Jasione (Bojňanský \& Fargašová, 2007), and therefore cannot be used as a reliable source of the data for diagnosing members of Campanulaceae of the flora of Ukraine. The anatomical structure of the fruit wall of $A$. canescens reveals the same traits as in C. latifolia examined by us earlier (Andreychuk \& Odintsova, 2019). The exocarpium and endocarpium are non-lignified, mesocarpium 
is parenchymatous, with chlorenchyma. Lignified elements - axicorns located only in the fruit septa. Openings in A. canescens are developed on the septum radii, as in $C$. latifolia. The differences between the species consist in the shape of axicorn and its location. In particular, the axicorns in $A$. canescens are round in the section, poorly developed, located in the upper part of septa, while in C. latifolia the axicorns have varying shape, wide and expanded to the fruit wall in the lower part and narrowed in the upper part, spreading through all the fruit length, and are well developed histologically (Andreychuk \& Odintsova, 2019).

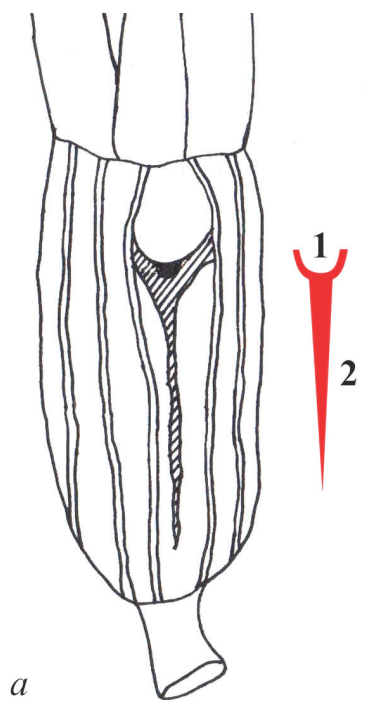

$b$

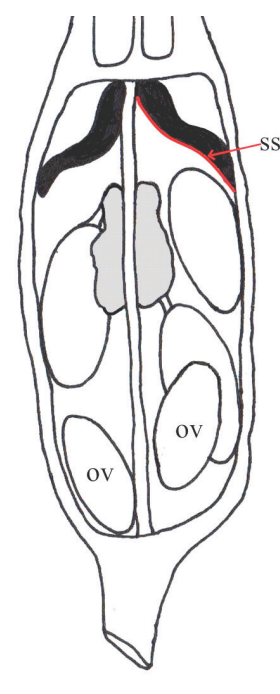

Fig. 8. Schematic image of the fruit $(a)$ and longitudinal section of the fruit (b) of $A$. canescens: $a$-opening is shaded, $b$-axicorns are marked in black, placentas are marked in grey; $o v$ - ovules, $s S$ - septifragal slit;

figure a presents the two stages of dehiscence of the fruit, indicated 1 and 2

Because of the absence of lignified elements in the fruit wall, the capsule of A. canescens belongs to the histogenetic Galanthus-type (Bobrov \& Romanov, 2019), however it has to be noted that dehiscence of the fruit is provided by the mechanical tissues distributed locally in fruit septa.

Comparison of the fruits of $A$. canescens and the species of Campanula revealed differences in fruit orientation during fruiting, on which the localization of openings at different height depends. Particularly, in erect fruits, the openings are located in the upper part of the capsule, while in pendant fruits - in the lower part (Kaden, 1964).

Fruits in different species of Campanula differ by localization of the openings: in members of the sectio Medium DC. the openings develop basally (Dremliuga, 2013b), while in members of the sectio Rapunculus (Fourr.) Boiss. - above the middle of the fruit (Dremliuga, 2013a). According to the localization of the openings, $A$. canescens is similar to section Rapunculus of the genus Campanula. Genera Phyteuma and Legousia are seen to be closely related to the representatives of this section (Roquet et al., 2008; Stefanovich \& Lakušić, 2009). However, in Asyneuma comosiforme Hayek \& Janch. and members of section Clinocarpium (Boiss.) Rech. f. \& Schiman-Czeika of the genus Asyneuma, the fruits are pendant and the openings are medial to basal (Lakušic et al., 2019), similarly to the section Medium DC. of genus Campanula, for example, C. latifolia (Andreychuk \& Odintsova, 2019). This is consistent with polyphyly of the genus Asyneuma determined using molecular methods (Stefanovich \& Lakušić, 2009).

The capsule of Asyneuma baldshuanicum (O. Fedtsch.) Fed. opens through pores on the middle height of the fruit (Artjuschenko \& Theodorov, 1986), while on the capsule of A. michauxioides the pores are located slightly above the middle of the fruit (Alçitepe, 2008).

In the other genera related to Campalula, the openings are also located in the upper part of the capsule. For example, in Phyteuma spicatum L. the capsule is trilocular, the pores are close to the top or at the middle of the fruit (Kolakovsky, 1995; Lammers, 2007). In Physoplexis comosa (L.) Schur the capsule is bilocular with pores at middle height (Lammers, 2007), the axicorns are poorly developed (Kolakovsky, 1995). In Legousia the capsule is trilocular, rarely unilocular, with medial or subapical po- res (Lammers, 2007), the axicorns are tongue-like, located at the upper part, with their bases attached to the top of central column. In all the listed genera the capsules are erect.

In A. comosiforme, $\mathrm{V}$-shaped valves covering large openings in the middle part of the fruit were found, with axicorns attached inside along the whole valve length (Lakušić et al., 2019). Similarly, in fruits of $C$. latifolia with basal openings, the axicorns spread along the septa from base to top of the fruit (Andreychuk \& Odintsova, 2019).

In $A$. canescens the axicorn is located only in a very small upper part of the septum. Hence, length of axicorns depends on the position of the opening in Campanula and Asyneuma species. In taxa with apical fruit openings (A. canescens), the axicorns are short, located only near the fruit roof, while in taxa with basal fruit openings (C. latifolia), the axicorns are long, spread throughout the capsule (Andreychuk \& Odintsova, 2019).

However, the openings in the fruits of the studied species develop according to the same principle: the axicorn makes a rupture in fruit wall on the lower margin of the dip, forming a hippocrepiform slit. The lower margin is oriented towards the peduncle, and with time the valve bends outward and bends during drying of the tissue.

For the plants with capsular fruits, it is important to classify the mode of dehiscence in a proper and detailed way, as Kolakovsky (1995) attempted to do for the Campanulaceae family. He determined the valvate (i.e. porate) and fissuricidal (with slits) axicorn types of the capsule. For genera Asyneuma, Phyteuma, Physoplexis, Trachelium, Campanula p. p., the other authors indicated the dehiscence through pores (podicidal dehiscence), while for Legousia and Campanula p. p. - dehiscence by the valves (Lammers, 2007; Lakušić et al., 2019), which does not entirely correspond to the Kolakovsky's (1995) division of the genera. Both terms, pore and valve, have discussable usage, since a pore is a small round opening in the fruit wall, while a valve is a fragment of the fruit wall, which bends and thus making an opening, usually, of a round shape.

Comparing our data on fruit dehiscence in species of Campanula and A. canescens, we came to the conclusion that there is a fundamental resemblance of development of the hippocrepiform slit and the opening covered with valve (stage 1 in A. canescens) in these taxa. Differential features of species are the location of the slit (basally or near the top), size of the slit (wide or narrow, long or short), and therefore size of the opening (small or large). The specific shape and morphogenesis of the opening and presence of the axicorns indicate the common origin of such a type of the opening inside a clade of closely related genera, including Campanula.

According to Kaden's (1964) classification, we determine the mechanism of fruit dehiscence through the axicorn slit or valve according to Kolakovsky (1995) as hippocrepiform dehiscence (dehiscentia hippocrepiformis) - the fruit opens with a non-closed slit in the form of horseshoe with formation of the valve on the septum radii, which opens two neighboring locules of the fruit simultaneously when it bends from the fruit wall. At the same time, the axicorns detach from the central column following a curved direction, which corresponds to septifragal dehiscence. For this reason, previously we identified the fruit of $C$. latifolia as an inferior capsule with septifragal-hippocrepiform dehiscence (Andreychuk \& Odintsova, 2019). The peculiarity of fruit dehiscence in A. canescens is the formation of additional slits on the septum radii after the hippocrepiform slit forms (stage 2). For A. canescens we propose to determine the mode of dehiscence as two-staged, septifragal-hippocrepiform and longitudinally-laminar dehiscence.

For the inferior fruits, we determined two types of dehiscence: formation of the openings in the lower part of the ovary (below the calyx) or in the upper part of the ovary, above the calyx (Odintsova, 2016). In A. canescens, as in the species of Campanula, the openings are formed in the tissues of the inferior part of the ovary.

\section{Conclusions}

As a result of the morpho-anatomical examination of the fruit in A. canescens, we revealed the type of placentation, anatomical structure of the fruit wall, features of formation of the openings in this species. The capsule of $A$. canescens does not contain lignified tissues in the fruit wall, however, dehiscence is provided by lignified parenchyma located in the fruit septa. Our study confirms the resemblance of dehiscence in A. canes- 
cens and species of the section Rapunculus of the genus Campanula with erect capsules. We consider it inexpedient to adopt a new fruit type for A. canescens, because the differences with species of Campanula concern only the small size of the axicorn slit and the appearance of additional slits for facilitating the seed release. We identify the fruit of $A$. canescens as an inferior trilocular syncarpous capsule with two-stage, hippocrepiform and laminar dehiscence.

\section{References}

Alçitepe, E. (2008). Morphological, anatomical and palynological studies on Asyneuma michauxioides (Campanulaceae). Biologia, 63(3), 338-342.

Andreychuk, R., \& Odintsova, A. (2019). Morphological and anatomical structure of Campanula latifolia L. fruits. Studia Biologica, 13(1), 95-105.

Andreychuk, R., \& Odintsova, A. (2020). Suchasnyi stan karpologichnykh doslidzen u rodyni Campanulaceae Juss. u zviazku zi systematykoiu [Actual state of carpological studies in the family Campanulaceae Juss. with regard to its systematics]. Studia Biologica, 14(2), 95-116 (in Ukrainian).

Artjuschenko, Z. T., \& Theodorov, A. A. (1986). Atlas po opisatelnoy morfologyi vysshykh rastenyi. Plod [Organographia illustrata plantarum vascularium. Fructus]. Nauka, Leningrad (in Russian).

Barykina, R. P., Veselova, T. D., Deviatov, A. G., Djalilova, H. H., Iljina, G. M., \& Chubatova, N. V. (2004). Spravochnik po botanicheskoj mikrotekhnike. Osnovy i metody [Handbook of the botanical microtechniques. Basics and Methods]. Moscow University Press, Moscow (in Russian).

Bobrov, A. V., \& Romanov, M. S. (2019). Morphogenesis of fruits and types of fruit of angiosperms. Botany Letters, 166(3), 366-399

Bojňanský, V., \& Fargašová, A. (2007). Atlas of seeds and fruits of Central and EastEuropean flora the Carpathian Mountains Region. Springer, Dordrecht.

BorschT., Korotkov,aN., Raus T., Lobin, W., \&LöhnęC. (2009). The petD group II intron as a species level marker: Utility for tree inference and species identification in the diverse genus Campanula (Campanulaceae). Willdenowia, 39, 7-33.

Dremliuga, N. G. (2013a). Morphological peculiarities of fruits of the species from subgenus Rapunculus (Fourr.) Boiss. of genus Campanula L. in the flora of Ukraine. Modern Phytomorphology, 4, 321-324.

Dremliuga, N. G. (2013b). The fruits' morphological peculiarities of species from section medium DC. of genus Campanula L. in the flora of Ukraine. Chomomors'ki Botanical Zournal, 9(1), 24-29.

Eddie, W. M. M., Shulkina, T., Gaskin, J., Haberle, R. C., \& Jansen, R. K. (2003) Phylogeny of Campanulaceae s. str. inferred from ITS sequences of nuclear ribosomal DNA. Annals of the Missouri Botanical Garden, 90(4), 554-575.

Fedina, L. A., Maslov, M. V., \& Gorovoy, P. G. (2016). New albiflorus forms of vascular plants on the Russian Far East. Acta Biologica Sibirica, 2(4), 110-117.

Haberle, R. C., Dang, A., Lee, T., Peñaflo,rC., Cortes-Burns, H., Oestreich, A., Raubeson, L., Cellinese, N., Edwards, E. J., Kim, S.-T., Eddie, W. M. M., \& Jansen, R. K. (2009). Taxonomic and biogeographic implications of a phylogenetic analysis of the Campanulaceae based on three chloroplast genes. Taxon, 58, 715-734

Kaden, N. N. (1964). Esche o sposobah vskrivaniya plodov [More details about types of fruit dehiscence]. Botanical Journal, 49(12), 1776-1779 (in Russian).
Kaden, N. N., \& Smimova, S. A. (1974). K metodike sostavleniya karpologicheskih opisaniy [Notes for the methods of compiling the carpological descriptions]. Naukova Dumka, Kyiv. Pp. 54-67 (in Russian).

Kallajxhiu, N., Naqellari, P., Pupuleku, B., \& Turku, S. (2014). Palynological description of five plants of different families in the Albanian region. International Journal of Botany and Research, 4(2), 31-38.

Khansari, E., Zarre, S., Alizadeh, K., Attar, F., Aghabeigi, F., \& Salmaki, Y. (2012). Pollen morphology of Campanula (Campanulaceae) and allied genera in Iran with special focus on its systematic implication. Flora, 207, 203-211.

Kim, H.-J., Son, D. C., Kim, H.-J., Choi, K., Oh, S.-H., \& Kang, S.-H. (2017). The chemotaxonomic classification of Korean Campanulaceae based on triterpene, sterol and polyacetylene contents. Biochemical Systematics and Ecology, 74, 11-18.

Kolakovsky, A. A. (1995). Semeystvo Kolokolchikovih [Family Campanulaceae]. Moscow (in Russian).

Lakušić, D., Eddie, W. M. M., Shuka, L., Lazarević, M., \& Barina, Z. (2019). The evolving "fate" of Asyneuma comosiforme: Validation of Hayekia, a new monotypic genus of Campanulaceae from Albania. Willdenowia, 49(1), 81-93.

Lammers, T. G. (2007). Campanulaceae. In: Kubitzki, K. (Ed.). The families and genera of vascular plants. VIII, Flowering plants - Eudicots: Asterales. Springer, Berlin. Pp. 26-56.

Mansion, G., Parolly, G., Crowl, A. A., Mavrodiev, E., Cellinese, N., Oganesian, M., Fraunhofer, K., Kamari, G., Phitos, D., Haberle, R., Akaydin, G., Ikinci, N., Raus, T., \& Borsch, T. (2012). How to handle speciose clades? Mass taxonsampling as a strategy towards illuminating the natural history of Campanula (Campanuloideae). PLoS One, 7(11), e50076.

Mosyakin, S. L., \& Fedoronchuk, M. M. (1999). Vascular plants of Ukraine. A nomenclatural checklist. M. G. Kholodny Institute of Botany, National Academy of Sciences of Ukraine, Kyiv.

Odintsova, A. (2016). Lokulitsydne rozkryvannia verkhnikh i nyzhnikh korobchastykh plodiv u poriadku Myrtales [Loculicidal dehiscence of superior and inferior capsular fruits in Myrtales]. Studia Biologica, 10(3-4), 129-140 (in Ukrainian).

Roquet, C., Sáez, L., Aldasoro, J. J., Susanna, A., Alarcón, M. L., \& Garcia-Jacas, N. (2008). Natural delineation, molecular phylogeny and floral evolution in Campanula. Systematic Botany, 33(1), 203-217.

Roquet, C., Sanmartín, I., Garcia-Jacas, N., Sáez, L., SusannąA., WikströmN., \& Aldasoro, J. J. (2009). Reconstructing the history of Campanulaceae with a Bayesian approach to molecular dating and dispersal-vicariance analyses. Molecular Phylogenetics and Evolution, 52, 575-587.

Roth, I. (1977). Fruits of Angiosperms. Gebrüder Borntraenger, Berlin, Stuttgart. Vol. 10(1).

Stefanovic, S., \& Lakušić, D. (2009). Molecular reappraisal confirms that the Campanula trichocalycina-pichleri complex belongs to Asyneuma (Campanulaceae). Botanica Serbica, 33, 21-31.

Visyulina, O. D. (1961). Rodyna Dzvonykovi [Family Campanulaceae]. In: Flora URSR. Academy of Science of the URSR, Kyiv. Vol. 10. Pp. 399-453 (in Ukrainian).

Yoo, K.-O., Crowl, A. A., Kim, K.-A., Cheon, K.-S., \& Cellinese, N. (2018). Origins of East Asian Campanuloideae (Campanulaceae) diversity. Molecular Phylogenetics and Evolution, 127, 468 474.

Zhuo, Z., Wen, J., Li, G., \& Sun, H. (2011). Phylogenetic assessment and biogeographic analyses of tribe Peracarpeae (Campanulaceae). Plant Systematics and Evolution, Springer. 